\title{
Indicator of Quality of Water for Human Consumption in the Community El Comején, Masaya (Nicaragua)
}

\author{
Dixon Nohel Morales López ${ }^{1}$, Ismael Montero Fernández ${ }^{2}$, Selvin Antonio Saravia Maldonado ${ }^{1}$, \\ Francisco Luis Acosta Díaz ${ }^{3} \&$ Luis Antonio Beltrán Alemán ${ }^{4}$ \\ ${ }^{1}$ Faculty of Earth Sciences and Conservation, National University of Agriculture, Catacamas, Olancho, \\ Honduras \\ ${ }^{2}$ Post-graduate Program in Biodiversity and Biotecnology, State Coordination of Roraima, Federal University of \\ Roraima, Campus Paricarana, Boa Vista, RR, Brazil \\ ${ }^{3 .}$ Faculty of Legal Sciences, National Autonomous University of Honduras, Bulevar Suyapa, Tegucigalpa, \\ Honduras \\ ${ }^{4}$ Post-graduate Program in Natural Resources, Federal University of Roraima, Campus Paricarana, Boa Vista, \\ RR, Brazil \\ Correspondence: Dixon Nohel Morales López, Faculty of Earth Sciences and Conservation, National University \\ of Agriculture, Highway to Dulce Nombre de Culmi, Km 215, Neighborhood El Espino, Catacamas, Olancho, \\ Honduras. Tel: 55-959-8408-6087. E-mail: dixonmorales15@yahoo.com
}

Received: December 23, 2018

Accepted: April 9, $2019 \quad$ Online Published: June 15, 2019

doi:10.5539/jas.v11n8p176

URL: https://doi.org/10.5539/jas.v11n8p176

\begin{abstract}
Knowing the quality of water for human consumption is of utmost importance in the development of a country, since the poor quality of this vital liquid can be a source of diseases for the health of the population. The present work was carried out in the community El Comején, Masaya, in the Republic of Nicaragua, where microbiological analyzes were carried out in three sampling points (one well drilled and two taps). The physicochemical and chemical analyzes are in accordance with the norms established by CARPE, highlighting sodium as a major element with a concentration of $48.6 \mathrm{mg} \mathrm{L}^{-1}$ and potassium with $21.08 \mathrm{mg} \mathrm{L}^{-1}$. On the other hand, biological parameters such as total coliforms, thermotolerable coliforms, E. coli and fecal enterococos were analyzed, being found in some sampling points, values of total coliforms of $110 \mathrm{NMP} 100 \mathrm{~mL}^{-1}$ being above the established limits, requiring a treatment additional to be suitable for human consumption.
\end{abstract}

Keywords: drinling water, water resources, pollution

\section{Introduction}

Water is a vital element for all the living beings of the planet, since the fluvial systems maintain terrestrial life and provide water to $95 \%$ of the world population (UNECLAC, 2013). However, anthropogenic pressures, especially in the agricultural sector, represent approximately $70 \%$ of all freshwater withdrawals worldwide, and more than $90 \%$ in most countries with lower human development indexes or those considered to be developing (WWAP, 2014). The unsustainable use of water for the production of large-scale crops depletes and contaminates aquifers, reduces the flow of rivers, degrades the habitats of the life of the flora and fauna, decreasing the availability and quality of water resources (FAO, 2011). In Latin America and the Caribbean, drinking water and sanitation services are still a problem worthy of attention, as more than 13 million urban inhabitants lack improved water sources and almost 61 million lack improved facilities. of Sanitation, a situation that is even more aggravating in the rural sector (BID, 2018).

According to Jouravlev (2011) the availability and quality of water is facing the great pressures of contamination, especially by the dumping of industrial quantities of waste rich in nitrogenous and phosphorous bases that are generating high levels of eutrophication of surface waters and coastal areas, it is expected that at the rate that is being contaminated increase by 2030 to $35 \%$. Groundwater supplies drinking water to at least $50 \%$ of the world's population, but this resource represents $43 \%$ of all water used for irrigation worldwide, 2.5 billion people depend exclusively on groundwater resources to meet their daily basic water needs (FAO, 2010). 
According to Alexandros and Bruinsma (2012) to year 2050, agriculture will have to produce $60 \%$ more food globally, and $100 \%$ more in developing countries, so it becomes a strong threat to contamination for bodies of fresh water.

Given that in recent years there has been a large population growth, thus diversifying the uses of water, have generated unwanted environmental conditions, such as the growth of the number of solid waste and other anthropogenic activities that accelerate the degradation of quality of water, being a worrisome situation, since according to the United Nations World Report on Water Resources Development in 2017 in Latin America only $8 \%$ of wastewater is subjected to some type of treatment.

In Nicaragua, there is a regulation that regulates the quality control of drinking water, called the Regional Coordinating Committee of Drinking Water and Sanitation Institutions of Central America, Panama and the Dominican Republic (CAPRE), March 1994, where the methods of analysis are specified., as well as the frequency and number of samples needed to establish quality control and the evaluation of the different measurement parameters.

According to the UNDP (2012) in Nicaragua in the 2007-2011 period, poverty and inequality among Nicaraguans were significantly reduced; the level of water and sanitation is among the lowest in the region. About $85 \%$ have access to improved water sources and about $52 \%$ use improved sanitation facilities.

This study was carried out with the support of the Center for the Investigation in Aquatic Resources of Nicaragua of the National Autonomous University of Nicaragua (CIRA/UNAN) with the objective of determining the problematic of the quality of water for consumption and of basic sanitation in the community El Comején, Department of Masaya, Republic of Nicaragua.

\section{Material and Methods}

\subsection{Local}

This work was carried out in the Republic of Nicaragua, specifically the community of El Comején, which is located at a distance of $10 \mathrm{~km}$ from the city of Masaya, limited to the North with Comején Uno, to the South with Las Flores, to the East with La Corteza and to the West with San José, this study was conducted under the coordination of the Aquatic Resources Research Center (CIRA) of the National Autonomous University of Nicaragua (Figure 1).

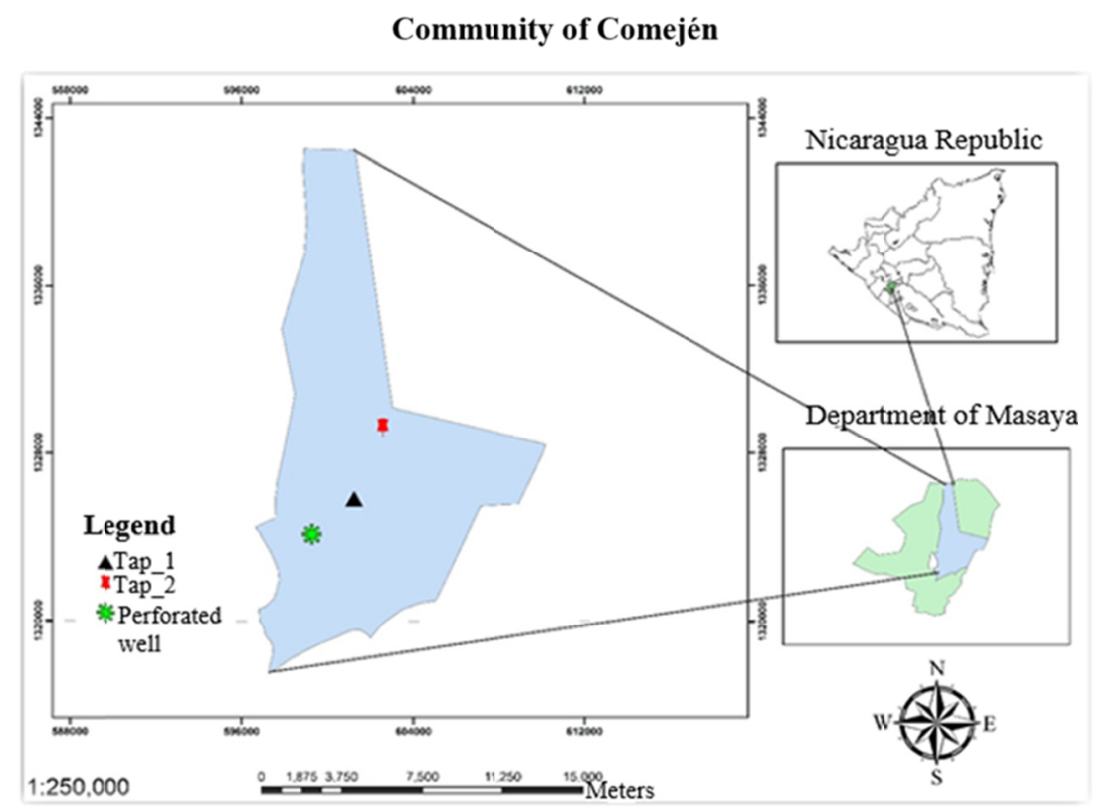

Figure 1. Comején community, Nicaragua

\subsection{Sampling Points}

Different sampling points were determined: one in the well drilled to the Northeast of the community of El Comején, the second point in a tap located to the north of the beginning of the distribution network and the third 
sampling point in a tap that is in the final part in the southern part of the water distribution network of the project in the community of El Comején. The samples were taken, refrigerated and suitably conditioned in the absence of light until the time of analysis.

\subsection{Parameters of Water Quality Indicators}

Physicochemical parameters (temperature, $\mathrm{pH}$, conductivity, residual chlorine and turbidity) were measured at the three sampling points, as well as bacteriological parameters (total coliforms, thermotolerable coliforms, Escherichia coli and Enterococci). At the same time, chemical indicators were also determined in the well drilled (calcium, magnesium, sodium, potassium, chlorides, nitrites, nitrates, ammonium, iron, fluorides, dissolved silica, water hardness and alkalinity), all determined in accordance with the methodology described by Mâcedo (2005).

\section{Results and Discussion}

\subsection{Parameters of Water Quality Indicators}

In Table 1, the physical-chemical parameters of field monitoring are presented in the community of El Comején, Masaya in Nicaragua for the three points studied.

Table 1. Physical-chemical parameters field in the community El Comején, Masaya-Nicaragua

\begin{tabular}{|c|c|c|c|c|}
\hline $\mathrm{pH}$ & $\mathrm{T}\left({ }^{\circ} \mathrm{C}\right)$ & Residual chlorine $\left(\mathrm{mg} \mathrm{L}^{-1}\right)$ & Conductivity $\left(\mu \mathrm{s} \mathrm{cm}^{-1}\right)$ & Turbidity (UTN) \\
\hline \multicolumn{5}{|c|}{ Perforated Well } \\
\hline 7.81 & 28.72 & 0 & 425 & 0.38 \\
\hline \multicolumn{5}{|c|}{ Tap 1} \\
\hline 7.94 & 31.10 & 0 & 409 & 0.50 \\
\hline \multicolumn{5}{|c|}{ Tap 2} \\
\hline 7.87 & 29.91 & 0 & 417 & 0.44 \\
\hline
\end{tabular}

The $\mathrm{pH}$ is important in the quality of water, since it controls both the balance of the chemical reactions that develop in the water and the biological activity that generally develops between values of $\mathrm{pH}$ 6-8 (De Souza, 2001), being the values of this work within those limits and within the recommendations (WHO, 1995). Electrical conductivity is a nonspecific property in water quality, but it gives us an idea of the total loads in solution as can be seen in Table 2, with the established parameters being higher than those recommended (WHO, 1995).

Finally, the importance of turbidity in water quality must be highlighted, since in human drinking water it protects human organisms from contamination and reflects the amount of materials, colors, minerals and organic matter present in the water, being able to be an indicator of water pollution (Espigares \& Fernández-Crehuet, 1999). In this work, the parameters measured are in accordance with the established limits (WHO, 1995).

\subsection{Chemical Parameters in the Well Drilled}

In Table 2, the chemical parameters analyzed in the drilling well are presented.

Table 2. Chemical parameters analyzed in the drilling well in the community El Comején, Masaya-Nicaragua

\begin{tabular}{ll}
\hline Parameters & Concentration \\
\hline $\mathrm{Ca}^{2+}\left(\mathrm{mg} \mathrm{L}^{-1}\right)$ & 20.04 \\
$\mathrm{Mg}^{2+}\left(\mathrm{mg} \mathrm{L} \mathrm{L}^{-1}\right)$ & 9.23 \\
$\mathrm{Na}^{+}\left(\mathrm{mg} \mathrm{L}^{-1}\right)$ & 48.6 \\
$\mathrm{~K}^{+}\left(\mathrm{mg} \mathrm{L}^{-1}\right)$ & 21.08 \\
Alkalinity $\left(\mathrm{mg} \mathrm{L}^{-1} \mathrm{CaCO}_{3}\right)$ & 176.2 \\
Hardness $\left(\mathrm{mg} \mathrm{L}^{-1} \mathrm{CaCO}_{3}\right)$ & 88.00 \\
$\mathrm{Fe}^{3+}\left(\mathrm{mg} \mathrm{L}^{-1}\right)$ & $<0.02$ \\
$\mathrm{SiO}_{4}^{2-}\left(\mathrm{mg} \mathrm{L}^{-1}\right)$ & 54.07 \\
$\mathrm{~F}^{-}\left(\mathrm{mg} \mathrm{L}^{-1}\right)$ & 0.26 \\
$\mathrm{NH}_{4}{ }^{3+}\left(\mathrm{mg} \mathrm{L}^{-1}\right)$ & 0.024 \\
$\mathrm{NO}_{2}{ }^{-}\left(\mathrm{mg} \mathrm{L}^{-1}\right)$ & $<0.003$ \\
$\mathrm{NO}_{3}^{-}\left(\mathrm{mg} \mathrm{L}^{-1}\right)$ & 13.31 \\
\hline
\end{tabular}


The major ions present in water are $\mathrm{Ca}^{2+}, \mathrm{Mg}^{2+}, \mathrm{Na}^{+}$and $\mathrm{K}^{+}$. Sodium is an essential element in the body, involved in the transmission of nervous impulse as well as participating in the processes of muscle contraction, potassium, related to the maintenance of heart rate and cellular integrity and on the other hand calcium is crucial in the processes of bone formation and blood coagulation (Sizer \& Whitney, 2003). Of all of them, sodium has a higher concentration, with a value of $48.6 \mathrm{mg} \mathrm{L}^{-1}$. Sodium is one of the most abundant elements on Earth, being soluble in water (Lucas et al., 2014). This ion reaches water from natural sources by leaching from rocks or from effluents from agricultural activities (Von Sperling, 2007). Potassium is associated with aluminosilicates and feldspar minerals, reaching groundwater as a result of mineral dissolution and, on the other hand, as decomposition of plants and agricultural residues (Clesceri et al., 1999).

The composition of the macro constituents reflects the low mineralization values. The dissolved salts are in concentration that are within the ranges for fresh water (Custodio \& Llamas, 1996), and the values of each of them are within the maximum admissible values for water for human consumption according to the norm (CAPRE, 1993).

For its part, alkalinity is defined as the ability of water to maintain its $\mathrm{pH}$ despite receiving acid or alkaline solution, the main effect of alkalinity being its reaction with certain cations in water, which leads to the formation of precipitates (Jiménez, 2001). According to the alkalinity ranges for fresh water provided by (WHO, 2016), the water studied has high alkalinity since water with values higher than $150 \mathrm{mg} \mathrm{L}^{-1}$ of $\mathrm{CaCO}_{3}$ are considered as high alkalinity.

The hardness of the water is mainly related to the amount of calcium and magnesium salts dissolved in it, being the degree of hardness in these salts, proportional to the concentration of said ions in the water (Rodriguez, 2009). This ion reaches water from natural sources by leaching from rocks or from effluents from agricultural activities. In this work were detected concentrations of Calcium of $20.04 \mathrm{mg} \mathrm{L}^{-1}$ and magnesium of $9.23 \mathrm{mg} \mathrm{L}^{-1}$ being within the normal parameters for water for human consumption according to the norm (CAPRE, 1993). The value obtained for the hardness of the water in this work is $88.00 \mathrm{mg} \mathrm{L}^{-1} \mathrm{CaCO}_{3}$ classified as hard water (range 121-180 mg L ${ }^{-1}$ $\mathrm{CaCO}_{3}$ ) According to the WHO, 1995 this range is in the recommended values that is $50 \mathrm{mg} \mathrm{L}^{-1} \mathrm{CaCO}_{3}$ or of total hardness expressed as calcium carbon.

As for iron, according to the (OPS, 1987) its presence in natural waters can be a consequence of the dissolution of rocks and minerals, in the water it occurs mainly in the bivalent and trivalent states (ferrous and ferric). In this work, the iron concentration found was lower than $0.02 \mathrm{mg} \mathrm{L}^{-1}$, being below the value admissible by the World Health Organization, which establishes the maximum value in water for human consumption of $0.3 \mathrm{mg} \mathrm{L}^{-1}$. It is an element that despite being beneficial to the body, when it is ingested in the human body in high concentrations, causes certain neurological disturbances as is the case of Alzheimer and Parkinson's disease as accumulation in body tissues (Fernández et al., 2007).

Other parameter determined was the content of dissolved silica, whose concentration is due to the dissolution of rocks containing silica such as quartz or sandstone. The concentration of dissolved silicates in this study was 54.07 $\mathrm{mg} \mathrm{L}^{-1}$ higher than the values determined by Twort et al. (2000) where concentrations vary between $1 \mathrm{mg} \mathrm{L}^{-1}$ for swampy waters and up to $40 \mathrm{mg} \mathrm{L}^{-1}$ for hard waters. According to the same author, no evidence has been found that constitutes health hazards, causing problems only in water pipes.

An analyte that can cause great problems for human health in water for human consumption is the presence of fluorides, being a problem worldwide. Fluoride concentrations come from fluorine, as it is an important element in the earth's crust, associated with fluorite or calcium fluoride, cryolite and apatite (Trejo-Vázquez et al., 1997). According to the World Health Organization, the fluoride levels in water for human consumption is $1.0 \mathrm{mg} \mathrm{L}^{-1}$ (WHO, 2006), with the level determined below the established values. This variation in fluoride concentrations in aquifers depends on several factors, mainly, the concentration of fluoride in the mineral, decomposition, discoloration, residence time and kinetics of the chemical reaction (Saxena \& Ahmed, 2001).

Nitrogen compounds are also present in natural waters and related to the nitrogen cycle, being its most abundant form in the atmosphere, being as a gaseous form with $78 \%$ volume, and in an oxidized form an important fraction in soils and organic substances (Miguel-Hernández \& Vázquez-Taset, 2006).

The same author, argues that nitrates are dissolved in water for human consumption, from the rocks of the subsoil and rarely by bacterial oxidation or from organic matter. In polluted or underground water does not exceed $10 \mathrm{mg} \mathrm{L}^{-1}$.

The nitrite in the state of intermediate oxidation of nitrogen, either by oxidation of ammonium to nitrate, or by reduction of nitrates, its presence is indicative of great microbiological activity. The nitrites naturally in water, 
according to Guerra (1979), are found in soils that contain $\mathrm{pH}$ values higher than 7.7 , although nitrogen fertilizers can also directly produce nitrites instead of nitrates when they are applied in alkaline soils from $\mathrm{pH}$ from 7 to 7.3 therefore, the slight existence of nitrite ions, are in line with the $\mathrm{pH}$ value determined in this work. The study carried out, the nitrite concentration is $<0.003 \mathrm{mg} \mathrm{L}^{-1}$, according to the CAPRE standards (1993) the admissible value is 0.10 or $3.00 \mathrm{mg} \mathrm{L}^{-1}$, the nitrate present $13.31 \mathrm{mg} \mathrm{L}^{-1}$, according to the CAPRE standards (1993), the admissible value is $50.00 \mathrm{mg} \mathrm{L}^{-1}$, and for ammonium it is $0.024 \mathrm{mg} \mathrm{L}^{-1}$, the maximum value admissible according to the CAPRE standards, 1993 is $0.5 \mathrm{mg} \mathrm{L}^{-1}$. The three analytes are below what is established by the CAPRE (1993) standards, that is, the three parameters are apt to be used in water for human consumption.

\subsection{Microbiological Parameters}

In Table 3, the values of total coliforms, thermotolerable coliforms, Escherichia coli and Enterococcus faecalis are considered for the well drilled.

Table 3. Microbiological parameters

\begin{tabular}{llll}
\hline Parameters & Perforated well & Tap 1 & Tap 2 \\
\hline Total coliforms (NMP $100 \mathrm{~mL}^{-1}$ ) & 4.5 & 110 & 110 \\
Thermotolerable coliforms $\left(\mathrm{NMP} 100 \mathrm{~mL}^{-1}\right)$ & N.D. & N.D. & 3.1 \\
E. coli $\left(\mathrm{UFC} \mathrm{g}^{-1}\right.$ ) & N.D. & N.D. & 1.3 \\
Enterococcus faecalis $\left(\mathrm{UFC} 100 \mathrm{~g}^{-1}\right)$ & N.D. & N.D. & 6.8 \\
\hline
\end{tabular}

Note. N.D. $=$ No Detected.

The presence of total coliforms is lower in the well drilled than in the two taps analyzed, being a parameter that must be interpreted according to the type of water, since the water that suffered disinfection, the total coliforms must be absent (Rego, Barros, \& dos Santos, 2010). The results of the TCs exceed the limits established by the water quality standards for human consumption that according to the WHO, 1995. No bacteriological contamination should be detected; in the CAPPRE standard, 1993. In order for water to be consumed, the maximum admissible value must be negative.

Thermotolerant coliforms are found in the intestinal tract of both humans and warm-blooded animals, being an important parameter in water for evaluating deficient hygienic-sanitary conditions (Silva et al., 2006), being only detected in tap 2 with a value of 3.1.

On the other hand, E. coli belongs to the Enterobacteriaceae family, being a facultative anaerobic bacterium, being one of the indicators of faecal contacmination most used in water quality (Larrea-Murell et al., 2013). It was only detected in refrigerator 3 with a value of $3.1 \mathrm{CFU} \mathrm{g}^{-1}$. The Enterococus genus is considered an efficient indicator to assess the quality of water since it is very resistant to the saline conditions of this medium and related to respiratory diseases, conjunctivites and dermatitis (Vergaray et al., 2007), being found only in tap 3 of the studied points.

Given the results of the microbiological parameters, from the bacteriological point of view the water of these three points can't be used for human consumption; however, it is recommended that an adequate methodology be established for its chlorination and monitoring of residual chlorine and other bacteriological analyzes be developed.

\section{Conclusion}

This work highlights the importance of carrying out water quality studies, especially in rural communities such as the one studied in this work where the continuous control of quality analytical parameters are scarce and in certain cases non-existent. The chemical parameters include high concentrations of calcium and potassium, mainly due to the types of minerals in the soil and, among the biological parameters, a high concentration of total coliforms in the taps, mainly due to the filtration of anthropogenic or waste residues animals.

\section{References}

Alexandratos, N., \& Bruinsma, J. (2012). World agriculture towards 2030/2050: The 2012 revision. ESA Working Paper $\mathrm{N}^{\mathrm{o}}$ 12-13. Rome.

BID (Banco Interamericano de Desenvolvimeinto). (2018). Proceso Regional de las Américas. Foro Mundial del Agua 2018, Informe Regional de América Laina y el Caribe, Informe Ejecutivo.

Clesceri, L., Greenberg, A., \& Eaton, A. (1999). Standard Methods for the Examination of Water and Wastewater 
(20th ed.). Water Environment Federation (WEF), Washington.

De Miguel-Hernández, C., \& Vázquez-Taset, Y. M. (2006). Origen o nitrate $\left(\mathrm{NO}_{3}\right)$ and nitrite $\left(\mathrm{NO}_{2}\right)$ and their influence in the potability of the underground waters. Mineria y Geologia, 22(3), 1-9.

De Souza, E. R. (2001). Noções sobre qualidade da água. Instituto Superior Técnico, Departamento de Engenharia Civil e Arquitectura, Lisboa.

Espigares, G. M., \& Fernández-Crehuet, M. (1999). Calidad del agua para consumo público: Caracteres físico-químicos en el estudio sanitario del agua (pp. 85-114). Granada, Spain.

FAO (Food and Agricultural Organization of the United Nations). (2010). Statistical database available in 2010. Retrieved from http://faostat.fao.org

FAO (Food and Agricultural Organization of the United Nations). (2011). The State of the World's Land and Water Resources for Food and Agriculture: Managing Systems at Risk. Retrieved from http://faostat.fao. org/docrep

Fernández, L. L., Fornari, L. H. T., Barbosa, M. V., \& Schroder, N. (2007). Iron and neurodegeneration. Scientia Medica, 17(4), 218-224.

Guerra, F. D. (1979). Edafologia general (p. 350). La Habana, DAP.

Jiménez, B. (2001). La contaminación ambiental en México: Causas, efectos y tecnología apropiada (p. 926). México, DF, Limusa.

Jouravlev, A. (2011). Importancia de los recursos hídricos para el desarrollo socioeconómico de la región (legislación hídrica en la adaptación al cambio climático): Definición de prioridades de investigación económica sobre la relación entre cambio climático y agua en la región. Panamá City, Brazil. Retrieved from http://www.eclac.cl/drmi/noticias

Larrea-Murrel, J. A., Rojas-Badía, M. M., Romeu-Álvarez, B., Rojas-Hernández, N. M., \& Heydrich-Pérez, M. (2013). Bacterias indicadoras de contaminación fecal en la evaluación de la calidad de las aguas: Revisión de literatura. Revista CENIC Ciencias Biológicas, 44(3), 24-34.

Lucas, A. A. T., Moura, A .S. A., Netto, A. de O. A., Facciol, G. G., \& Sousa, I. F. (2014). Qualidade da água no riacho Jacaré, Sergipe e Brasil usada para irrigação. Revista Brasileira de Agricultura Irrigada, 8(2), 98-105. https://doi.org/10.7127/rbai.v8n200228

Macedo, J. A. de B. (2005). Métodos laboratoriais de análises físico-químicas e microbiológicas (p. 450). Consejo Regional de Química, Minas Gerais.

OMS. (2004). Fluoride um drinking-water. Background document for development of WHO Guidelines for drinking-water quality (p. 9). World Health Organization.

PNUD (Plan Nacional de Desarrollo Humano). (2012). Nicaragua (p. 203). Retrieved from http://www.pndh. gob.ni/docuemntos/pndhActualizado/pndh.pdf

Rego, N. A. C., Barros, S. R., \& dos Santos, J. W. B. (2010). Avaliação esapacotemporal da concentração de coliformes termotolerantes na Lagoa Ecantada, Ilheus-BA. Revista Eletrônica do Prodema, 4(1), 55-69.

Rodríguez, J., Vargas, E., \& Gómez, M. (2009). Procesos Industriales: Manual de laboratorio para el análisis químico y control de calidad. Heredia, C.R.

Saxena, V., \& Ahmed, S. (2001). Dissolution of fluoride in groundwater: A wáter-rock interaction study. Environ. Geol., 40, 1084-1087. https://doi.org/10.1007/s002540100290

Sizer, F. S., \& Whitney, E. N. (2003). Nutrição: Conceitos e controvérsias (p. 769). Barueri, SP.

Trejo-Vázquez. R., Alarcón, M. T., Martínez, Y., Romero, \& Salvador, J. (1997). Niveles de fluoruros en el agua de los pozos de la ciudad de Durango. Ing. Hidrául. Mex., 12, 51-57.

Twort, A., Ratnayaka, D., \& Brandt, M. (2000). Water Supply (p. 725). Elsevier Ltd. Great Britain.

UNECLAC (United Nations Economic Commission for Latin America and the Caribbean). (2013). Economic Survey of Latin America and the Caribbean. Santiago, Chile.

Vergaray, G., Méndez, C. R., Morante, H. Y., Heredia, V. I., \& Béjar, V. R. (2007). Enterococus y Escherichia coli como indicadores de contaminación fecal en playas costeras de Lima. Revista del Instituto de Investigación de la Facultad de Ingenieria Geológica, Minera, Metalúrgica y Geográfica, 10(20), 6-82.

Von Sperling, M. (2007). Estudos de modelagem da qualidade da água de rios (p. 452). Belo Horizonte. 
WWAP (World Water Assessment Programme). (2014). The United Nations World Water Development Report 2014: Water and Energy (p. 230). Paris, France.

\section{Copyrights}

Copyright for this article is retained by the author(s), with first publication rights granted to the journal.

This is an open-access article distributed under the terms and conditions of the Creative Commons Attribution license (http://creativecommons.org/licenses/by/4.0/). 